\title{
Analisis Bibliometrik Perkembangan Penelitian Bank Wakaf
}

\section{Ujang Syahrul Mubarrok, Zulfia Rahmawati}

Universitas Islam Kadiri

ujang@uniska-kediri.ac.id, zulfiarahmawati@uniska-kediri.ac.id

\section{Article Info}

Article history:

Received Oct19th, 2020

Revised Oct 30th, 2020

Accepted Nov 5th, 2020

Keyword:

Bibliometrics,

Bank Waqf,

Islamic Economics

Copyright@2020 Program Studi Ekonomi Syariah

Universitas Yudharta Pasuruan

All rights reserved.

DOI: https://doi.org/10.35891/ml.v12i1.1938

\section{Corresponding Author:}

Ujang Syahrul Mubarrok, lecturer at Kadiri Islamic University

Email: ujang@uniska-kediri.ac.id

\begin{abstract}
Waqf bank has an important role in the framework of convenience and community empowerment. However, research on waqf banks is still limited. This research aims to map the development of research on waqf banks. Using bibliometric analysis of articles about waqf banks on Google Schoolar with the help of Publish or Perish software. This study found that there were 53 articles about complete waqf banks, first published in 2012, which studied a qualitative approach with the theme of the role of waqf banks. The benefits of this research can be used as a consideration to determine the field of research in waqf bank research.
\end{abstract}




\section{A. Pendahuluan}

Kemiskinan merupakan masalah yang harus diselesaikan bagi pembangunan di berbagai negara di dunia termasuk di Indonesia. Kemiskinan seringkali ditandai dengan pengangguran, kelaparan, kekurangan gizi dan keterbelakangan mental. Kemiskinan di Indonesia masih menjadi masalah penting bagi usaha pencapaian kesejahteraan masyarakat Indonesia. Angka kemiskinan menurut rilis BPS menyebutkan persentase penduduk miskin pada Maret 2019 sebesar 9, 41 persen atau 25,14 juta orang (Badan Pusat Statistik, 2019).

Selain masalah kemiskinan juga masalah kesenjangan ekonomi antar penduduk Indonesia tergolong tinggi. Termasuk juga pemerataan pembangunan dimana kemajuan ekonomi terkonsentrasi di perkotaan, sementara di pedesaan masih banyak yang belum ada pembangunan secara maksimal.

Upaya pengentasan kemiskinan terus dikerjakan oleh pemerintah diantarannya dengan memperbesar anggaran negara untuk penanggulangan kemiskinan (Gustani \& Suhada, 2016). Tidak hanya itu, kegiatan-kegiatan dalam rangka menggerakkan aktivitas perekonomian juga banyak dilakukan. Roda aktivitas perekenomian dipacu dengan proyek-proyek infrastruktur seperti pembangunan bandara, jalan tol dan bendungan.

Upaya pengentasan kemiskinan dalam rangka mewujudkan Indonesia yang sejahtera diantaranya dapat dilakukan dengan memberdayakan masyarakat miskin. Usaha tersebut mampu mengentaskan kemiskinan juga dapat mengurangi kesenjangan pendapatan. Peran pemberdayaan tersebut salah satunya bisa dilakukan oleh bank wakaf dengan memaksimalkan potensi wakaf di Indonesia. Hal ini sudah dilakukan oleh Pemerintahan Jokowi melalui OJK dengan memberikan izin Bank Wakaf yang hingga pertengahan Maret tahun 2018 berjumlah 20 Bank Wakaf (Huda, 2018).

Wakaf selama ini diidentikkan kepada benda wakaf yang tidak bergerak seperti tanah dan bangunan, sedangkan wakaf benda bergerak baru ramai belakangan ini. Wakaf benda bergerak misalnya dalam bentuk uang (Faujiah, 2018a). Maka, kehadiran bank wakaf sangat dibutuhkan untuk mengelolanya.

Dewasa ini peran bank wakaf tidak hanya sebagai lembaga bisnis semata tetapi bisa berperan aspek sosial dengan memberdayakan potensinya untuk kesejahteraan masyarakat. Namun di sisi lain, riset dan pengembangan terkait bank wakaf masih kurang, padahal riset ini sangat penting dilakukan

Berdasarkan latar belakang tersebut, penulis tertarik untuk membahas masalah perkembangan riset tentang bank wakaf. Pertanyaan yang akan dijawab dalam penelitian ini adalah (1) Berapa jumlah publikasi tentang wakaf setiap tahunnya?; (2) secara pendekatan metodologi, bagaimana komposisi penelitian tentang bank wakaf?; (3) Apa saja subjek area penelitian tentang bank wakaf?. Tujuan dari penelitian ini adalah mengetahui sejauh mana potret perkembangan riset tentang bank wakaf di Indonesia. Manfaat penelitian ini dapat digunakan sebagai dasar untuk menentukan area riset dalam penelitian bank wakaf. 


\section{B. Kajian Teori}

\section{Bank wakaf}

Pengertian bank wakaf tentu tidak bisa dilepaskan dari pengertian bank. Bank merupakan badan usaha yang menghimpun dana dari masyarakat dalam bentuk simpanan dan menyalurkannya kepada masyarakat dalam bentuk kredit dengan tujuan meningkatkan kesejahteraan masyarakat.

Berdasarkan pengertian bank tersebut, pengertian bank wakaf yaitu lembaga yang menghimpun dana dari donatur dan meyalurkannya kepada masyarakat miskin. Havita et al., (2014) menyebutkan Bank wakaf dimaksudkan sebagai bank yang bebas bunga, nirlaba, dan sosial yang modal utamanya digunakan untuk kejahteraan sosial, penyediaan pembiyaan mikro dan pembangunan ekonomi kaum miskin.

\section{Gambar 1}

Skema Bisnis Bank Wakaf

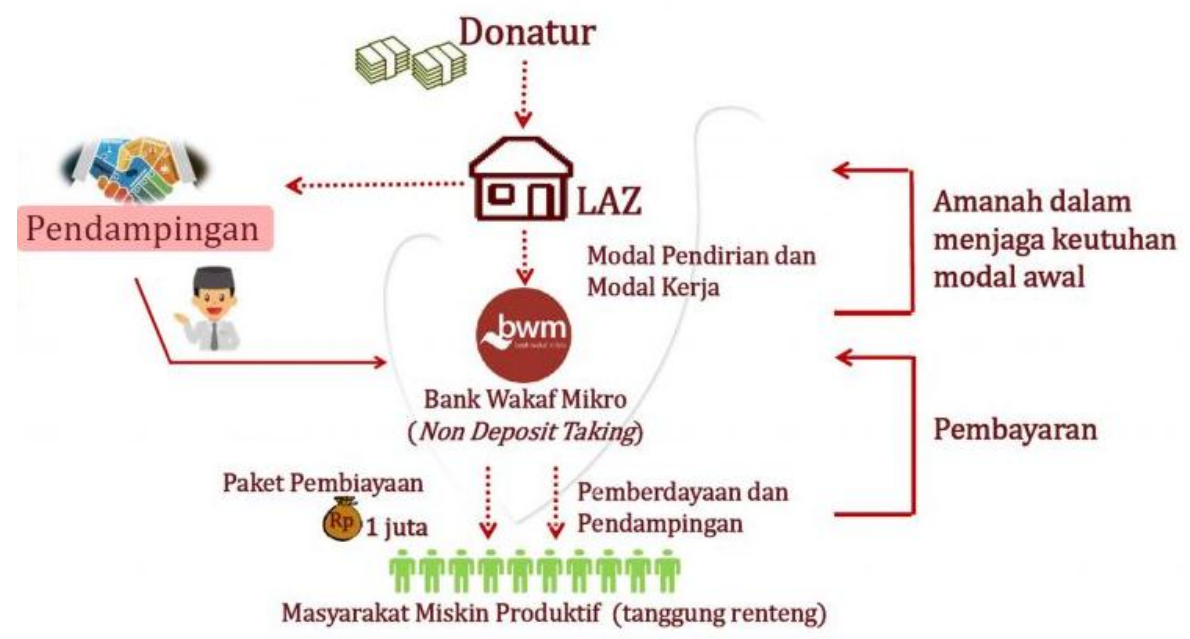

Sumber: Otoritas Jasa Keuangan, 2018.

Gambar 1 menunjukkan operasional bank wakaf dimana modal dasar diperoleh dari donatur langsung atau dana yang dihimpun melalui Lembaga Amil Zakat (LAZ). Selain sebagai donatur, LAZ memiliki kewajiban untuk melakukan pendampingan ke bank wakaf maupun nasabahnya meliputi pendampingan usaha, manajemen serta pendampingan agama. Dana yang didapatkan bank wakaf dari donatur kemudian digunakan untuk pembiayaan usaha dan pemberdayaan masyarakat miskin produktif secara tanggung renteng. Hasil usaha masyarakat miskin sebagian digunakan untuk pembayaran angsuran pembiayaan yang akan dikembangkan lagi oleh bank wakaf.

\section{Analisis Bibliometrik}

Studi bibliometrik merupakan salah satu cara untuk mengamati tren penelitian dari berbagai macam publikasi artikel. Analisis bibliometrik merupakan satu kajian anlisis bibliografi kegiatan ilmiah yang berbasis pada asumsi bahwa seorang peneliti harus menghubungkan penelitiannya dengan penelitian yang lain. Hal ini akan memberikan kemajuan dan perkembangan pengetahuan berkaitan dengan topik 
tertentu (Tupan et al., 2018). Dalam analisis bibliometrik, penelitian akan mengungkapkan perkembangan literatur seperti jumlah publikasi, subyek artikel, pendekatan penelitian dan produktivitas pengarang.

\section{Metode}

Penelitian ini menggunakan data sekunder berupa artikel ilmiah berbahasa indonesia yang diperoleh dari google schoolar (GS). Metodologi yang digunakan dalam penelitian ini adalah metode kualitatif dengan statistik deskriptif studi literatur pada artikel ilmiah yang berkaitan dengan bank wakaf. Metode kualitatif adalah metode penelitian yang berlandaskan pada filsafat post-positivisme digunakan untuk meneliti pada kondisi objek alamiah, dimana peneliti sebagai instrumen kunci, teknik pengumpulan data dilakukan secara triangulasi, analisis data bersifat induktif, dan hasil penelitian kualitatif lebih menekankan makna dari pada generalisasi (Sugiyono, 2013). Statistik deskriptif digunakan dalam penyajian data dalam bentuk tabel atau grafik sebagai dasar untuk pengambilan keputusan.

Tahapan dalam penelitian ini mengikuti langkah Fahiminia et al (2015) dalam melakukan kajian teori meliputi 4 langkah, yaitu: mendefinisikan kata kunci, hasil pencarian awal, penyempurnaan hasil pencarian, menyusun statistik pada data awal dan analisis data (Fahimnia et al., 2015). Tahapan lebih detail sebagai berikut:

1. Menentukan kata kunci pencarian.

Pencarian literatur dilakukan pada 6 April 2020 dengan menggunakan perangkat lunak Publish or Perish (PoP) dengan database GS yang digunakan untuk mengumpulkan data. Pencarian pada PoP menggunakan title words 'bank wakaf'.

2. Hasil pencarian awal

Hasil pencarian awal pada PoP memperoleh 58 artikel yang terbit dimulai tahun 2012 sampai 2020 dalam bentuk jurnal, artikel proseding dan skripsi/tesis.

3. Penyempurnaan hasil pencarian

Hasil pencarian awal menghasilkan artikel dengan berbagai bentuk dan sumber.

Kemudian kami memisahkan artikel yang tidak sesuai kriteria berdasarkan tabel sebanyak 5 artikel. Sehingga artikel yang sempurna untuk dianalisis adalah 53 artikel.

Tabel 1

Kriteria penolakan artikel

\begin{tabular}{|c|c|}
\hline Kriteria & Jumlah artikel \\
\hline Data tidak tersedia & 2 \\
\hline Opini & 1 \\
\hline Artikel ganda & 2 \\
\hline Total & 5 \\
\hline
\end{tabular}

Sumber: data diolah, 2020.

4. Menyusun statistik

Hasil pencarian setelah adanya penyempurnaan yang berjumlah 53 artikel kemudian diunduh dalam format RIS untuk di export ke perangkat lunak mendeley. Prose 
selanjutnya adalah melengkapi semua informasi penting yang meliputi judul, penulis, jurnal publikasi dan abstrak di mendeley. Setelah lengkap semua informasi artikel kemudian menyusun statistik pengklasifikasian ke dalam tahun publikasi, pendekatan penelitia dan subyek area penelitian.

5. Analisis data

Analisis pada penelitian ini berupa temuan-temuan yang didapatkan dari kajian literatur terhadap artikel yang berkaitan dengan bank wakaf.

\section{Hasil dan Pembahasan}

\section{Jumlah Publikasi per Tahun}

Pada bagian ini menjelaskan jumlah publikasi artikel dari tahun 2012 sampai tahun 2020. Ada 53 artikel yang berkaitan dengan wakaf diambil dari Google Schoolar melalui perangkat lunak PoP. Tabel 2 menunjukkan artikel pertama kali terbit pada tahun 2012 sebanyak 1 artikel. Publikasi terbanyak ada pada tahun 2019 sebanyak 37 artikel. Sedangkan pada tahun 2013 tidak ada artikel yang publikasi.

Tabel 2

Jumlah publikasi per tahun

\begin{tabular}{|c|c|}
\hline Tahun & Jumlah Publikasi \\
\hline 2012 & 1 \\
\hline 2013 & - \\
\hline 2014 & 1 \\
\hline 2015 & 2 \\
\hline 2016 & 2 \\
\hline 2017 & 1 \\
\hline 2018 & 6 \\
\hline 2019 & 37 \\
\hline 2020 & 3 \\
\hline Total & 53 \\
\hline
\end{tabular}

Sumber: data diolah, 2020.

Tabel 3 memperlihatkan jenis publikasi jurnal yang diamati. Publikasi dalam bentuk artikel jurnal ada 21 artikel, publikasi artikel proseding ada 5, dalam bentuk bab buku ada 1, dan publikasi terbanyak dalam bentuk skripsi atau tesis sebanyak 26 buah.

Tabel 3

Jenis publikasi

\begin{tabular}{|l|c|c|c|c|c|c|c|c|c|c|}
\hline \multirow{2}{*}{ Jenis publikasi } & \multicolumn{8}{|c|}{ Tahun Publikasi } & \multirow{2}{*}{ Total } \\
\cline { 2 - 13 } & 2012 & 2013 & 2014 & 2015 & 2016 & 2017 & 2018 & 2019 & 2020 & \\
\hline Artikel Jurnal & - & - & 1 & 2 & - & 1 & - & 16 & 1 & 21 \\
\hline Artikel Proseding & - & - & - & - & 1 & - & 4 & - & - & 5 \\
\hline Skripsi/Tesis & 1 & - & - & - & 1 & - & 2 & 21 & 1 & 26 \\
\hline Bab Buku & - & - & - & - & - & - & - & - & 1 & 1 \\
\hline Total & 1 & - & 1 & 2 & 2 & 1 & 6 & 37 & 3 & 53 \\
\hline
\end{tabular}

Sumber: data diolah, 2020. 
..:: Malia: Jurnal Ekonomi Islam Vol. 12 No. 1, Desember 2020 ::..

\section{Pendekatan penelitian masing-masing artikel.}

Pendekatan penelitian yang digunakan merujuk pada (Sugiyono, 2013) dimana ada 3 jenis penedekatan penelitian yaitu pendekatan kualitatif, pendekatan kuantitatif dan pendekatan campuran. Tabel 4 menunjukkan pendekatan penelitian yang digunakan masing-masing artikel. Dalam penelitian ini, pendekatan yang paling banyak digunakan adalah pendekatan kualitatif sebanyak 52 artikel, sedangkan pendekatan kuantitatif hanya 1 artikel, dan tidak ada yang menggunakan pendekatan campuran.

Tabel 4

Pendekatan penelitian

\begin{tabular}{|c|c|c|c|c|}
\hline \multirow{2}{*}{ Tahun Publikasi } & \multicolumn{3}{|c|}{ Pendekatan } & \multirow{2}{*}{ Total } \\
\cline { 2 - 4 } & Kualitatif & Kuantitatif & Campuran & \\
\hline 2012 & 1 & - & - & 1 \\
\hline 2013 & & - & - & - \\
\hline 2014 & 1 & - & - & 1 \\
\hline 2015 & 2 & - & - & 2 \\
\hline 2016 & 2 & - & - & 2 \\
\hline 2017 & 1 & - & - & 1 \\
\hline 2018 & 6 & - & - & 6 \\
\hline 2019 & 36 & 1 & - & 37 \\
\hline 2020 & 3 & - & - & 3 \\
\hline Total & 52 & 1 & - & 53 \\
\hline
\end{tabular}

Sumber: data diolah, 2020.

\section{Subjek Area Penelitian (Manajemen, Hukum, Kemiskinan dll)}

Tabel 5 menunjukkan subjek pembahasan setiap artikel yang dalam observasi ini meliputi manajemen, aspek hukum dan peran dari bank wakaf. Artikel yang membahas tentang manajemen bank wakaf sebanyak 12 artikel, aspek hukum sebanyak 14 artikel. Pembahasan terbanyak berkaitan dengan peran bank wakaf baik dalam pemberdayaan maupun pengentasan keminskinan sebanyak 27 artikel.

Tabel 5

Subjek area penelitian

\begin{tabular}{|l|c|c|c|c|c|c|c|c|c|c|}
\hline \multirow{2}{*}{ Subyek artikel } & \multicolumn{7}{|c|}{ Tahun Publikasi } & \multirow{2}{*}{ Total } \\
\cline { 2 - 13 } & 2012 & 2013 & 2014 & 2015 & 2016 & 2017 & 2018 & 2019 & 2020 & \\
\hline Manajemen & 1 & - & - & 1 & - & - & 2 & 7 & 1 & 12 \\
\hline Aspek Hukum & - & - & - & 1 & 1 & - & 1 & 10 & 1 & 14 \\
\hline Peran & - & - & 1 & - & 1 & 1 & 3 & 20 & 1 & 27 \\
\hline \multicolumn{1}{|c|}{ Total } & 1 & - & 1 & 2 & 2 & 1 & 6 & 37 & 3 & 53 \\
\hline
\end{tabular}

Sumber: data diolah, 2020.

Topik manajemen artikel tentang wakaf sebagaimana pada tabel 6 meliputi pengelolaan dana wakaf, manajemen likuiditas, pengelolaan pembiayaan dan manajemen strategi pemasaran. Topik aspek hukum yang diangkat pada penelitian 
bank wakaf meliputi tinjauan hukum dan fatwa yang berkaitan dengan bank wakaf, kedudukan dan legalitas, penyelesaian sengketan dan aspek hukum pemberdayaan dana wakaf. Topik peran bank wakaf sangat mendominasi dalam penelitian tentang wakaf yang meliputi topik mengatasi kemiskinan, pemberdayaan UMKM, pemberdayaan ekonomi, penguatan sektor pertanian, pemberdayaan pesantren dan intermediasi sosial.

Tabel 6

Topik penelitian

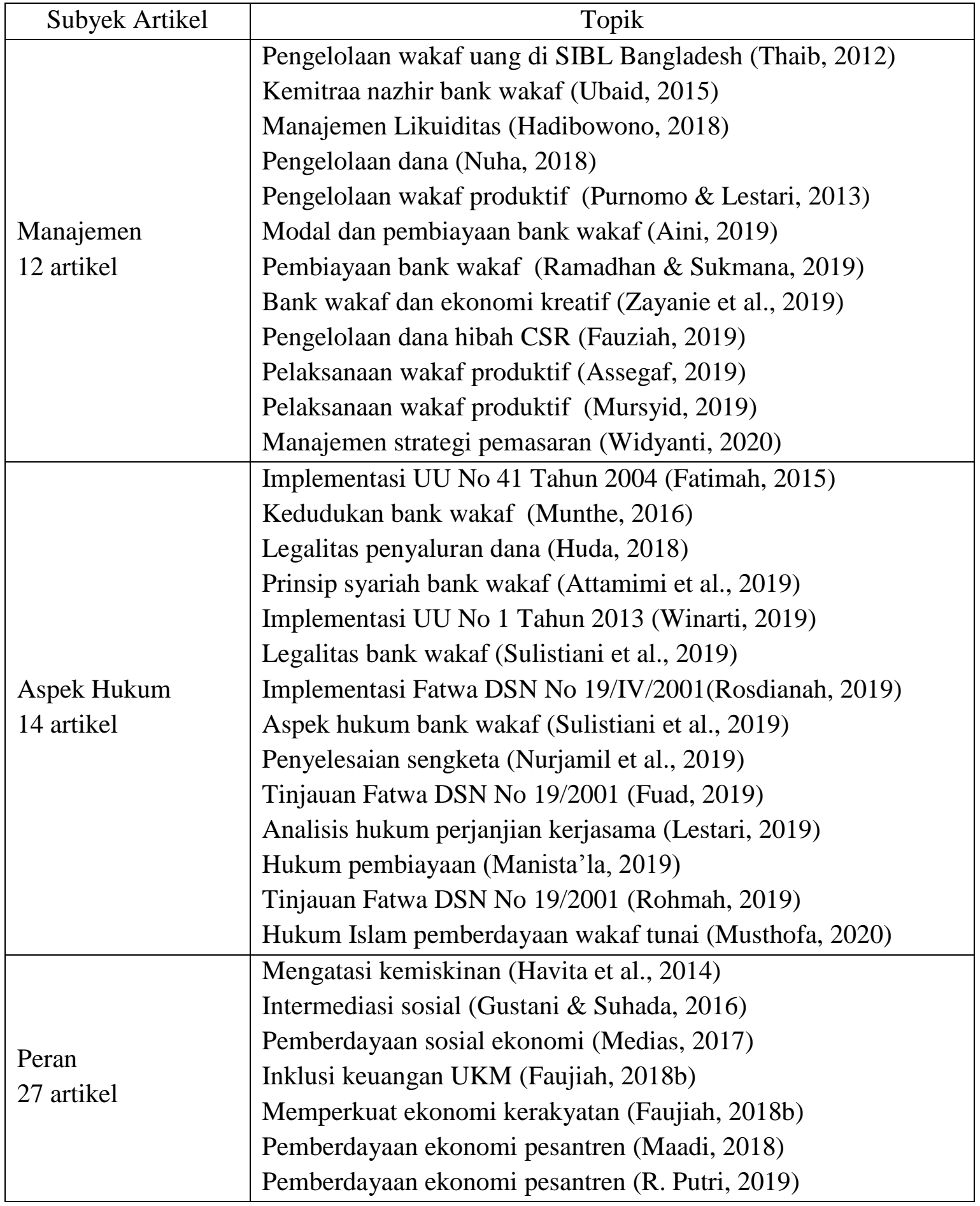




\begin{tabular}{|l|l|}
\hline Pemberdayaan masyarakat (Ragaseta, 2019) \\
Pemberdayaan ekonomi masyarakat (Disemadi \& Roisah, 2019) \\
Pemberdayaan UKM (T. P. Putri, 2019) \\
Pemberdayaan usaha mikro pesantren (Nur et al., 2019) \\
Pemberdayaan ekonomi masyarakat (Harahap et al., 2019) \\
Pengembangan UMKM (Aini, 2019) \\
Pemberdayaan wakaf produktif (Pebrian, 2019) \\
Penguatan modal (Ramadhan, 2019) \\
Pemberdayaan UMKM (Balqis \& Sartono, 2019) \\
Pemberdayaan masyarakat miskin (S. Nurhayati, 2019) \\
Pemberdayaan pelaku usaha (Aisyah, 2019) \\
Mengurangi kemiskinan (Safitri \& Sukmana, 2019) \\
Pemberdayaan usaha mikro (E. Nurhayati, 2019) \\
Pemberdayaan ekonomi umat (Sofiyani, 2019) \\
Pengentasan kemiskinan (Fitaloka, 2019) \\
Mengurangi kemiskinan (Safitri \& Sukmana, 2019) \\
Penguatan sektor pertanian (Istikomah, 2019) \\
Pemberdayaan usaha mikro (E. Nurhayati et al., 2019) \\
Pemberdayaan usaha kecil (Nur et al., 2019) \\
Pemberdayaan wakaf tunai (Musthofa, 2020)
\end{tabular}

Sumber: data diolah, 2020.

\section{Temuan penelitian}

Ada beberapa temuan terkait penelitian ini. Analisis dari 55 jurnal yang berkaitan dengan bank wakaf menghasilkan temuan sebagai berikut:

a. Artikel tentang bank wakaf ditemukan paling awal tahun 2012, namun mulai banyak dipublikasikan pada tahun 2018 dan puncaknya pada tahun 2019 ada 37 artikel. Jenis publikasi terbanyak dalam bentuk skripsi atau tesis.

b. Pendekatan penelitian tentang bank wakaf yang digunakan sebagian besar pendekatan kualitatif, sehingga terbuka peluang lebar untuk menggunakan pendekatan kuantitaitif dalam penelitian tentang bank wakaf.

c. Subyek area penelitian didominasi penelitian tentang peran bank wakaf dalam pemberdayaan dan pengentasan kemiskinan kemudian aspek hukum dan manajemen bank wakaf.

\section{E. Kesimpulan}

Penelitian tentang bank wakaf memiliki peran penting dalam ekonomi Islam demi kesuksesan pemberdayaan masyarakat untuk mencapai kesejahteraan. Meskipun lambat dalam memulai, namun semakin marak pada tahun belakangan ini. Hal ini menunjukkan bahwa bank wakaf menjadi penelitin yang menarik bagi peneliti dengan tema pembahasan yang masih luas. 
Saran berdasarkan penelitian ini adalah harapan untuk peneliti ekonomi Islam ada sebagian yang konsen meneliti tentang bank wakaf. Dan bagi penelitian selanjutny diharapkan bisa menambah basis data tidak hanya dari Google Schoolar namun menambahkan dengan basis data Scopus dan Microsof Academic yang sudah ada dalam pilihan menu di PoP.

\section{DAFTAR PUSTAKA}

Aini, Q. (2019). Pengaruh modal dan pembiayaan Bank Wakaf Mikro Syariah terhadap perkembangan usaha mikro kecil menengah (UMKM) pada Bank Wakaf Mikro Syariah Berkah Rizqy Lirboyo Kediri. etheses.uin-malang.ac.id.

Aisyah, S. (2019). Optimalisasi peran Bank Wakaf Mikro dalam pemberdayaan ekonomi pelaku usaha sekitar pesantren di Jawa Timur. UIN Sunan Ampel Surabaya.

Assegaf, M. (2019). Pelaksanaan Wakaf Produktif Di Bank Wakaf Mikro Syariah Denanyar Jombang. Management of Zakat and Waqf Journal (Mazawa), 1(1), 66-78.

Attamimi, Z. F., Disemadi, H. S., \& Santoso, B. (2019). Prinsip Syariah Dalam Penyelenggaraan Bank Wakaf Mikro Sebagai Perlindungan Hak Spiritual Nasabah. Jurnal Jurisprudence, 9(2), 117-132.

Balqis, W. G., \& Sartono, T. (2019). Bank Wakaf Mikro sebagai sarana pemberdayaan pada usaha mikro, kecil dan mengah. Jurisdictie: Jurnal Hukum Dan Syariah, 10(2), 215231.

Disemadi, H. S., \& Roisah, K. (2019). Kebijakan Model Bisnis Bank Wakaf Mikro Sebagai Solusi Pemberdayaan Ekonomi Masyarakat. Law Reform, 15(2), 177-194.

Fahimnia, B., Sarkis, J., \& Davarzani, H. (2015). Green supply chain management: A review and bibliometric analysis. In International Journal of Production Economics (Vol. 162). Elsevier. https://doi.org/10.1016/j.ijpe.2015.01.003

Fatimah, S. (2015). Implementasi Wakaf Tunai Dalam UU No 41 Tahun 2004 di Bank Muamalat Indonesia Lampung Timur. Jurnal As-Salam, 4(2), 19-37.

Faujiah, A. (2018a). Bank Wakaf Mikro Dan Pengaruhnya Terhadap Inklusi Keuangan Pelaku Usaha Kecil Dan Mikro (UKM). 2nd Proceedings of Annual Conference for Muslim Scholars.

Faujiah, A. (2018b). Peran bank wakaf dalam upaya memperkuat ekonomi kerakyatan. Temu Ilmiah Nasional Penelitian Tahun 2018, 649-660.

Fauziah, S. (2019). Analisis Pengelolaan Dana Hibah CSR (Corporate Social Responsibility) Oleh Bank Wakaf Mikro Di Indonesia Perspektif Hukum Syariah Studi Kasus Di Bank Wakaf Mikro An-Nawawi Tanara Serang Banten. repository.iiq.ac.id. 
Fitaloka, F. (2019). Implementasi Konsep Pengentasan Kemiskinan Dalam Perspektif Islam Di Bank Wakaf Mikro Al Fitrah Wava Mandiri. UIN Sunan Ampel Surabaya.

Fuad, L. (2019). Tinjauan Fatwa DSN MUI Nomor 19 Tahun 2001 Terhadap Implementasi Pembiayaan Qard Di Bank Wakaf Mikro Al Fitrah Wava Mandiri Surabaya. Management of Zakat and Waqf Journal (MAZAWA), 1(1), 55-65.

Gustani, \& Suhada. (2016). Bank Wakaf Sebagai Lembaga Intermediasi Sosial (Suatu Inovasi Pemberdayaan Wakaf Tunai Untuk Meningkatkan Kesejahteraan Umat). Forum Riset Perbankan Syariah V, 1-22.

Hadibowono, S. (2018). Manajemen Likuiditas Bank Wakaf Mikro Untuk Menjamin Keberlangsungan Usaha (Going Concern) Studi Kasus Pondok Pesantren Al Fitrah Surabaya. repository.unair.ac.id.

Harahap, I., Mailin, \& Amini, S. (2019). Peran Bank Wakaf Mikro Syariah Di Pesantren Mawaridussalam Dalam Pemberdayaan Ekonomi Masyarakat. TANSIQ: Jurnal Manajemen Dan Bisnis Islam, 2(2), 154-164.

Havita, G., Sayekti, K. A., \& Wafiroh, S. R. (2014). Model Bank Wakaf di Indonesia Dalam Potensinya Untuk Mengembangkan Wakaf Uang dan Mengatasi Kemiskinan. Program Kreativitas Mahasiswa.

Huda, B. (2018). Legalitas Penyaluran Harta Zakat dan Bantuan Non Muslim sebagai Dana Wakaf pada Bank Wakaf Mikro Perspektif Fikih. Proceedings of Annual Conference for Muslim Scholars.

Istikomah, I. (2019). Penguatan Sektor Pertanian Melalui Bank Wakaf Tani Berbasis Mudharabah. TAWAZUN: Journal of Sharia Economic Law, 2(2), 135-146.

Lestari, N. D. (2019). Analisis Hukum Terhadap Perjanjian Kerjasama Antara LAZNAS BSM Umat dengan Lembaga Keuangan Mikro Syariah-Bank Wakaf Mikro Almuna Berkah Mandiri. etd.repository.ugm.ac.id.

Maadi, A. S. (2018). Instrumen Bank Wakaf Mikro: Alternatif Pemberdayaan Ekonomi Pesantren. Proceeding of Annual Conference for Muslim Scholars, 449-454.

Manista'la, H. (2019). Mekanisme Pembiayaan Bank Wakaf Mikro Ponpes Futuhiyyah Mranggen Demak Perspektif Hukum (Study Kasus di Ponpes Futuhiyyah Mranggen Demak). e-repository.perpus.iainsalatiga.ac ....

Munthe, A. K. (2016). Kedudukan bank wakaf dalam sistem peraturan perundang-undangan di Indonesia. digilib.ui.ac.id.

Mursyid, K. (2019). Pelaksanaan Wakaf Produktif di Bank Wakaf Mikro Syariah Denanyar Jombang. UIN Sunan Ampel Surabaya.

Musthofa, A. M. (2020). Sistem Pemberdayaan Wakaf Tunai di Bank Wakaf Alpansa Klaten Perspektif Hukum Islam. eprints.ums.ac.id.

26 | Analisis Bibliometrik Perkembangan Penelitian Bank Wakaf 
Nuha, M. R. (2018). Pengelolaan dana Bank Wakaf Mikro di LKMS Amanah Makmur Sejahtera Kota Kediri Ditinjau Dari Manajemen Syariah. etheses.iainkediri.ac.id.

Nur, M. A., Muharrami, R. S., \& Arifin, M. R. (2019). Peranan Bank Wakaf Mikro dalam Pemberdayaan Usaha Kecil pada Lingkungan Pesantren. Journal of Finance and Islamic Banking, 2(1), 25-49.

Nurhayati, E. (2019). Analisis Model Pembiayaan Bank Wakaf Dalam Pemberdayaan Usaha Mikro Syariah (Studi Kasus: Bank Wakaf Mikro El-Manahij, Pondok Pesantren Manahijussadat Lebak. repository.uinbanten.ac.id.

Nurhayati, E., Rustamunadi, R., \& Fitriyah, D. (2019). Analisis Model Pembiayaan Bank Wakaf Dalam Pemberdayaan Usaha Mikro Syariah (Studi Kasus: Bank Wakaf Mikro El-Manahij, Pondok Pesantren Manahijussadat, Lebak). Tazkiya, 20(1), 91-114.

Nurhayati, S. (2019). Model Pemberdayaan Ekonomi Masyarakat Miskin Melalui Akses Pembiayaan Bank Wakaf Mikro Berbasis Pesantren. Eco-Iqtioshadi: Jurnal Ilmiah Ekonomi Dan Keuangan Syariah, 1(1), 45-56.

Nurjamil, S. N., Agung, A., \& Risnaningsih, I. (2019). Model Penyelesaian Sengketa Pembiayaan Bermasalah Pada Bank Wakaf Mikro Berbasis Pesantren. Res Nullius Law Journal, 1(1), 85-97.

Pebrian, R. (2019). Model pemberdayaan Wakaf Produktif pada usaha mikro: Analisis Praktik Qardh Bank Wakaf Mikro Bahrul Ulum Barokah Sejahtera Tambakberas Jombang. etheses.uin-malang.ac.id.

Purnomo, R., \& Lestari, S. (2013). Terhadap Perkembangan Usaha Mikro Mustahik ( Penerima Zakat ) ( Studi Kasus Rumah Zakat Kota Semarang ). In Jurnal Bisnis dan Ekonomi (JBE).

Putri, R. (2019). Bank Wakaf Mikro sebagai Program Pemberdayaan Ekonomi Umat di Lingkungan Pondok Pesantren: studi kasus Bank Wakaf Mikro Alpen Barokah Mandiri PP Al-Amien Prenduan SUmenep. UIN Sunan Ampel Surabaya.

Putri, T. P. (2019). Pemberdayaan usaha mikro kecil dan menengah (UMKM) oleh bank wakaf mikro (Studi kasus bank wakaf mikro Almuna Berkah Mandiri Pondok Pesantren Al-Munawwir Krapyak. In repository.umy.ac.id. Universitas Muhammadiyah Yogyakarta.

Ragaseta, A. Y. (2019). Pemberdayaan Masyarakat Dengan Sistem Halmi (Halaqoh Mingguan) Pada Bank Wakaf Mikroalmuna Berkah Mandiri. dspace.uii.ac.id.

Ramadhan, M. F. (2019). Perbedaan Keuntungan Penjualan Pelaku Usaha Mikro Sebelum dan Sesudah Mendapatkan Pembiayaan Dari Bank Wakaf Mikro Surabaya. repository.unair.ac.id. 
Ramadhan, M. F., \& Sukmana, R. (2019). Peran Bank Wakaf Mikro Dalam Penguatan Modal dan Pemberdayaan Usaha Mikro di Surabaya. Jurnal Ekonomi Syariah Teori Dan Terapan, 6(11), 2172-2184.

Rohmah, R. (2019). Tinjauan Fatwa DSN MUI No 19 Tahun 2001 terhadap implementasi pembiayaan Qardh di Bank Wakaf Mikro Al Fitrah Wava Mandiri Surabaya. UIN Sunan Ampel Surabaya.

Rosdianah, S. (2019). Implementasi Fatwa DSN-MUI NO. 19/IV/2001 tentang qardh pada Bank Wakaf Mikro (Studi di Bank Wakaf Mikro Pesantren An-Nawawi Tanara SerangBanten). repository.uinbanten.ac.id.

Safitri, R. A., \& Sukmana, R. (2019). Efektivitas Bank Wakaf Mikro Dalam Mengurangi Kemiskinan (Studi Kasus Lkms Denanyar Sumber Barokah). In Jurnal Ekonomi Syariah Teori dan Terapan.

Sofiyani, S. (2019). Pemberdayaan Ekonomi Umat Melalui Bank Wakaf Mikro",(Studi di Pondok Pesantren An-Nawawi Tanara Kabupaten Serang-Banten). repository.uinbanten.ac.id.

Sugiyono. (2013). Metode Penelitian Bisnis. CV. Alfabeta.

Sulistiani, S. L., Yunus, M., \& Bayuni, E. M. (2019). Aspek hukum Bank Wakaf Mikro dalam pengentasan kemiskinan berbasis pesantren di Indonesia. Jurnal Bimas Islam, 12(1), 1-26.

Thaib, K. U. (2012). Pemberdayaan wakaf uang di Social Islami Bank Limited Bangladesh. repository.uin-suska.ac.id.

Tupan, Rahayu, R. N., Rachmawati, R., \& Rahayu, E. S. R. (2018). Analisis bibliometrik perkembangan penelitian bidang ilmu instrumentasi. BACA: Jurnal Dokumentasi Dan Informasi, 39(2), 135-149.

Ubaid, A. (2015). Kemitraan Nazhir dengan Bank Syariah dalam Mengembangkan Wakaf Uang: Studi Perbandingan di Indonesia, Bangladesh dan Yordania. Kuriositas: Media Komunikasi Sosial Dan ..., 8(1), 15-24.

Widyanti, A. (2020). Strategy Marketing Of Sharia Banks Of Micro Sharia Wakaf In Increasing The Number Of Customers (Case Study: Typical Islamic Micro Waqf Bank). Journal of Sosial Science, 1(1).

Winarti. (2019). Sistem pengoperasian Bank Wakaf Mikro (BWM) menurut Uu No. 1 Tahun 2013 tentang lembaga keuangan mikro dan Uu No. 41 Tahun 2004 tentang wakaf. In repository.uinjkt.ac.id. UIN Syarif Hidayatullah.

Zayanie, J. M., Fitria, A., \& Kamariah, R. (2019). Bank Wakaf Mikro and Creative Economics in Pesantren Buntet. Shirkah: Journal of Economics and ..., 4(2), 289-312. 